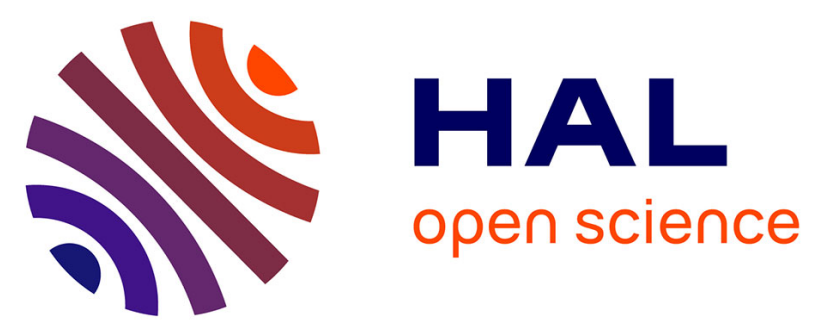

\title{
From the seismic cycle to long-term deformation: linking seismic coupling and Quaternary coastal geomorphology along the Andean megathrust
}

Marianne Saillard, Laurence Audin, B. Rousset, Jean-Philippe Avouac, M. Chlieh, S. R. Hall, L. Husson, D. L. Farber

\section{To cite this version:}

Marianne Saillard, Laurence Audin, B. Rousset, Jean-Philippe Avouac, M. Chlieh, et al.. From the seismic cycle to long-term deformation: linking seismic coupling and Quaternary coastal geomorphology along the Andean megathrust. Tectonics, 2017, 36 (2), pp.241 - 256. 10.1002/2016TC004156 . hal-01524436

\section{HAL Id: hal-01524436 \\ https://hal.science/hal-01524436}

Submitted on 26 May 2021

HAL is a multi-disciplinary open access archive for the deposit and dissemination of scientific research documents, whether they are published or not. The documents may come from teaching and research institutions in France or abroad, or from public or private research centers.
L'archive ouverte pluridisciplinaire HAL, est destinée au dépôt et à la diffusion de documents scientifiques de niveau recherche, publiés ou non, émanant des établissements d'enseignement et de recherche français ou étrangers, des laboratoires publics ou privés. 


\section{Tectonics}

\section{RESEARCH ARTICLE}

10.1002/2016TC004156

Key Points:

- Peninsulas are seismic barriers and show locally high Quaternary uplift rates $(>0.4 \mathrm{~m} / \mathrm{ka})$

- They tend to form above aseismically sliding areas and are permanent over multiple seismic cycles

- These dynamic features reflect anelastic deformation of the fore arc in response to the subduction seismic cycle

Supporting Information:

- Supporting Information S1

Correspondence to:

M. Saillard,

marianne.saillard@ird.fr

\section{Citation:}

Saillard, M., L. Audin, B. Rousset,

J.-P. Avouac, M. Chlieh, S. R. Hall,

L. Husson, and D. L. Farber (2017), From

the seismic cycle to long-term

deformation: linking seismic coupling

and Quaternary coastal geomorphology

along the Andean megathrust,

Tectonics, 36, 241-256, doi:10.1002/

2016 TC004156.

Received 10 FEB 2016

Accepted 21 JAN 2017

Accepted article online 25 JAN 2017

Published online 9 FEB 2017

C2017. American Geophysical Union. All Rights Reserved.

\section{From the seismic cycle to long-term deformation: linking seismic coupling and Quaternary coastal geomorphology along the Andean megathrust}

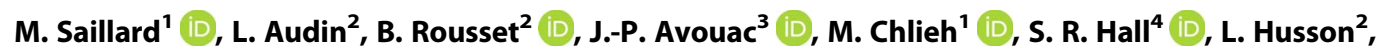 \\ and D. L. Farber ${ }^{5,6}$ \\ ${ }^{1}$ Université Côte d'Azur, IRD, CNRS, Observatoire de la Côte d'Azur, Géoazur, Valbonne, France, ${ }^{2}$ IRD, CNRS, Université \\ Grenoble Alpes, ISTerre, Grenoble, France, ${ }^{3}$ Tectonics Observatory, Division of Geological and Planetary Sciences, California \\ Institute of Technology, Pasadena, California, USA, ${ }^{4}$ Earth Sciences Department, College of the Atlantic, Bar Harbor, Maine, \\ USA, ${ }^{5}$ Earth and Planetary Sciences Department, University of California, Santa Cruz, California, USA, ${ }^{6}$ Lawrence Livermore \\ National Laboratory, Livermore, California, USA
}

Abstract Measurement of interseismic strain along subduction zones reveals the location of both locked asperities, which might rupture during megathrust earthquakes, and creeping zones, which tend to arrest such seismic ruptures. The heterogeneous pattern of interseismic coupling presumably relates to spatial variations of frictional properties along the subduction interface and may also show up in the fore-arc morphology. To investigate this hypothesis, we compiled information on the extent of earthquake ruptures for the last 500 years and uplift rates derived from dated marine terraces along the South American coastline from central Peru to southern Chile. We additionally calculated a new interseismic coupling model for that same area based on a compilation of GPS data. We show that the coastline geometry, characterized by the distance between the coast and the trench; the latitudinal variations of long-term uplift rates; and the spatial pattern of interseismic coupling are correlated. Zones of faster and long-term permanent coastal uplift, evidenced by uplifted marine terraces, coincide with peninsulas and also with areas of creep on the megathrust where slip is mostly aseismic and tend to arrest seismic ruptures. We conclude that spatial variations of frictional properties along the megathrust dictate the tectono-geomorphological evolution of the coastal zone and the extent of seismic ruptures along strike.

\section{Introduction}

Over the last few decades, a number of $M>8.5$ earthquakes occurred at locations along subduction zones where only much smaller earthquakes had been documented previously [Ammon et al., 2005; Lay, 2015]. This pattern suggests that a portion of a subduction zone can rupture either in more frequent smaller or, plausibly, less frequent larger earthquakes [e.g., Kanamori and McNally, 1982; Thatcher, 1990]. The observation is particularly evident in the historical record of earthquakes along the Peru-Chile megathrust, where the Nazca plate is subducting beneath South America (Figure 1). Despite along strike variability, stationarity seems to characterize the location of seismic rupture limits, suggesting that the subduction zone along the Peru-Chile margin is characterized by "segmentation" [Ando, 1975]. Segmentation is also shown in geodetic measurements of interseismic and postseismic strains in South America. As observed in other subduction zones, seismic ruptures (1) tend to correlate with asperity patches that are highly locked during the interseismic period and (2) tend to arrest at patches where slip is mostly aseismic, either due to interseismic or postseismic creep [e.g., Chlieh et al., 2008; Perfettini et al., 2010; Moreno et al., 2010; Métois et al., 2012; Protti et al., 2014]. This correlation is interpreted to result from the spatial variation of megathrust friction along and across strike [Burgmann et al., 2005; Kaneko et al., 2010; Hetland and Simons, 2010; Cubas et al., 2013; Schurr et al., 2012].

Spatial variations in fore-arc morphology also bear information regarding the frictional properties along the subduction interface that have been observed to correlate with the extent of megathrust ruptures [e.g., Marshall and Anderson, 1995; von Huene and Klaeschen, 1999; Fuller et al., 2006; Audin et al., 2008; Rehak et al., 2008; Rosenau and Oncken, 2009; Bejar-Pizarro et al., 2013; Cubas et al., 2013; van Dinther et al., 2013]. The margins of South America and Japan provide examples of this relationship between the fore-arc morphology and megathrust ruptures as in both locations the coastline seems to mark the downdip limit of the seismogenic portion of the megathrust [Ruff and Tichelaar, 1996; Khazaradze and Klotz, 2003]. During 


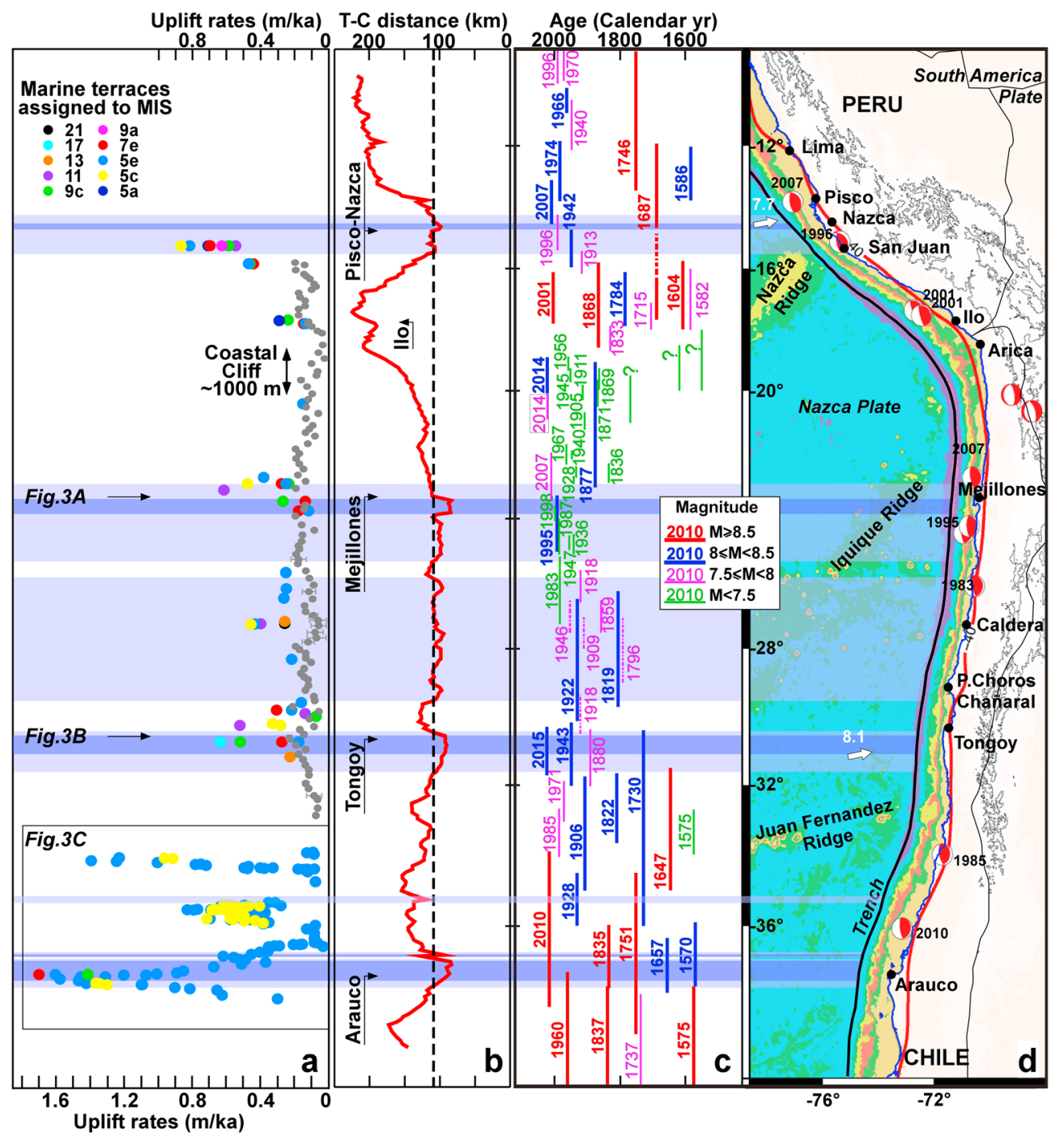

Figure 1. Marine terrace uplift rates, trench-coast distance, and rupture length of historical earthquakes along the Andean margin. (a) Uplift rates of marine terraces reported in the literature (we present the average rate since terrace abandonment; Table S1 in the supporting information [Jara-Muñoz et al., 2015]). Each color corresponds to a marine terrace assigned to a marine isotopic stage (MIS). Gray dots are the uplift rates of the central Andean rasa estimated from a numerical model of landscape evolution [Melnick, 2016]. (b) The distance between the coast and the trench was measured parallel to the convergence direction [DeMets et al., 1994]. Main peninsulas are indicated with names and arrows. Horizontal blue bands are the areas where the coastline is less than $110 \mathrm{~km}$ (light blue) or $90 \mathrm{~km}$ (dark blue) from the trench. (c) Lateral extent of the rupture zone of historical megathrust earthquakes are color coded by magnitude from southern Chile to central Peru (reported in Table S2). Continuous lines indicate the rupture zones better constrained than those represented by dashed lines. (d) Geodynamic setting of the Andean margin $\left(10^{\circ} \mathrm{S}-40^{\circ} \mathrm{S}\right)$ and location of major great historical megathrust earthquakes. Major bathymetric features, the coastline (blue line), and the Peru-Chile trench (thick black line) are indicated. Convergence directions and velocities $(\mathrm{cm} / \mathrm{yr})$ of the Nazca plate toward the South America plate are from DeMets et al. [1994]. Red line corresponds to the $40 \mathrm{~km}$ isodepth of the subducting slab [Hayes and Wald, 2009].

the 1960 Chile earthquake, most of the slip occurred offshore [e.g., Moreno et al., 2011]. Further, during the 2007 Pisco earthquake the locally contorted coastline separates the uplifted, offshore area from the subsided, onshore area, indicating that the rupture occurred updip of the coastline [Sladen et al., 2010]. This relationship is consistent with the observation that the downdip edge of the locked portion of the megathrust determined from modeling of interseismic strain follows the coastline quite closely [Chlieh et al., 2004; Bejar-Pizarro et al., 2013]. Another observation linking fore-arc morphology to the spatial occurrences of megathrust earthquake ruptures is that the ruptures tend to correlate with fore-arc basins and arrest at locations where there are trench-perpendicular gravity highs that correspond to local topographic fore-arc highs 


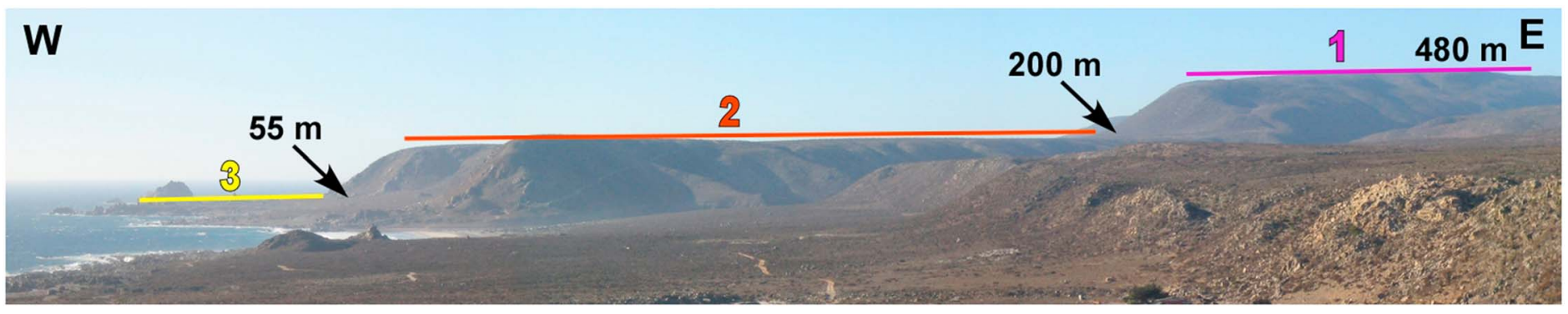

Figure 2. Panorama view of a stair-cased sequence of at least three marine terrace levels uplifted at $\sim 55, \sim 200$, and $\sim 480 \mathrm{~m}$ of elevation at Punta Villa Señor (Chile, $\sim 30.5^{\circ} \mathrm{S}$ ). The oldest level is at the highest elevation and the youngest at the lowest elevation (photo by M. Saillard).

[Mogi, 1969; Nishenko and McCann, 1979; Song and Simons, 2003; Wells et al., 2003; Llenos and McGuire, 2007]. Indeed, along the coasts of Japan, Alaska, and South America, seismic ruptures tend to stop close to peninsulas or coastal promontories [Wells et al., 2003; Melnick et al., 2009; Cubas et al., 2013].

Taken together, these observations suggest that the morphology of fore arcs, and the location and shape of the coastline in particular, could be used to assess megathrust segmentation during large interplate earthquakes. In this study, we test the hypothesis that the coastline geometry and kinematics (uplift and subsidence) reflect the spatial variations of frictional properties of the megathrust and, in turn, the seismic segmentation of the megathrust offshore South America. In this study, we assess correlations among three types of quantitative data from central Peru to southern Chile (between $\sim 12^{\circ} \mathrm{S}$ and $\sim 40^{\circ} \mathrm{S}$ ): (1) coastal uplift rates derived from the elevation of dated marine terraces (Figure 2 and Table S1 in the supporting information); (2) the distance between the trench and the coast in the convergence direction; and (3) the pattern of interseismic coupling, a quantity defined as the ratio of the deficit of slip rate during the interseismic period divided by the long-term slip rate [cf. Avouac, 2015]. This ratio quantifies the degree of locking along the plate interface. A null interseismic coupling means that the subduction interface is creeping at the long-term slip rate (no slip deficit is building up). An interseismic coupling of 1 means that the subduction interface is fully locked. We compare the spatial variations of these three data sets with the latitudinal distribution of historical earthquake rupture zones for the last 500 years (see Table S2 for references).

\section{Long-Term Coastal Dynamics of the Andean Margin}

Along the western Andean margin, the Nazca plate is subducting eastward beneath South America at a rate varying from 7.7 in southern Peru to $8.1 \mathrm{~cm} / \mathrm{yr}$ in southern Chile, respectively [DeMets et al., 1994] (Figure 1). A number of geomorphological studies have characterized coastal uplift from marine terraces (see Table S1 for references), which provide reliable long-term records of past sea level highstands (odd marine isotopic stage (MIS); Figure 2) [Lajoie, 1986; Chappell and Shackleton, 1986; Pedoja et al., 2011]. As present-day sea level is higher than the highest levels recorded since the early Pleistocene, any Pleistocene coastal features standing above the present sea level must reflect tectonic uplift [Lajoie, 1986].

Stair-cased marine terrace sequences are preserved discontinuously along the coast of Peru and Chile (Figure 1). Well-preserved wave-cut platforms are more commonly found on peninsulas and promontories, in particular at San Juan de Marcona, Ilo, Mejillones, Tongoy, and Arauco (Figure 1). Built marine terraces are also found in bays where the wave-cut planation surface is covered by deposits due to lower wave energy [Trenhaile, 1987, 2000; Sunamura, 1992; Bloom, 1998]. Marine terraces typically date from about 800 ka to $<10$ ka [Regard et al., 2010] (see Figure 1a and Table S1 for references). Recent efforts in surveying and dating these coastal features using in situ produced cosmogenic nuclide exposure dating have provided robust constraints on the rates and patterns of local coastal uplift along most of the coast of Peru and Chile [Marquardt et al., 2004; Quezada et al., 2007; Saillard, 2008; Melnick et al., 2009; Saillard et al., 2009, 2011; Cortès et al., 2012; Jara-Muñoz et al., 2015]. These data reveal spatiotemporally variable uplift rates along and across strike during the last million years [Saillard et al., 2009, 2012] (Figure 1a). Mean uplift rates are moderate to high and range between 0.1 and $1.7 \mathrm{~m} / \mathrm{ka}$ (Figure 1a). The higher number and elevation of preserved marine terraces on peninsulas (i.e., San Juan de Marcona $\left(\sim 15.3^{\circ} \mathrm{S}\right)$, Mejillones $\left(\sim 23.5^{\circ} \mathrm{S}\right)$, and Arauco Peninsulas $\left.\left(\sim 37.5^{\circ} \mathrm{S}\right)\right)$ suggest faster active uplift of these areas than other locations along the coastal fore arc (e.g., between Mejillones and Caldera; Figure 1). Where uplift has been more subdued (or potentially periods of subsidence), the 

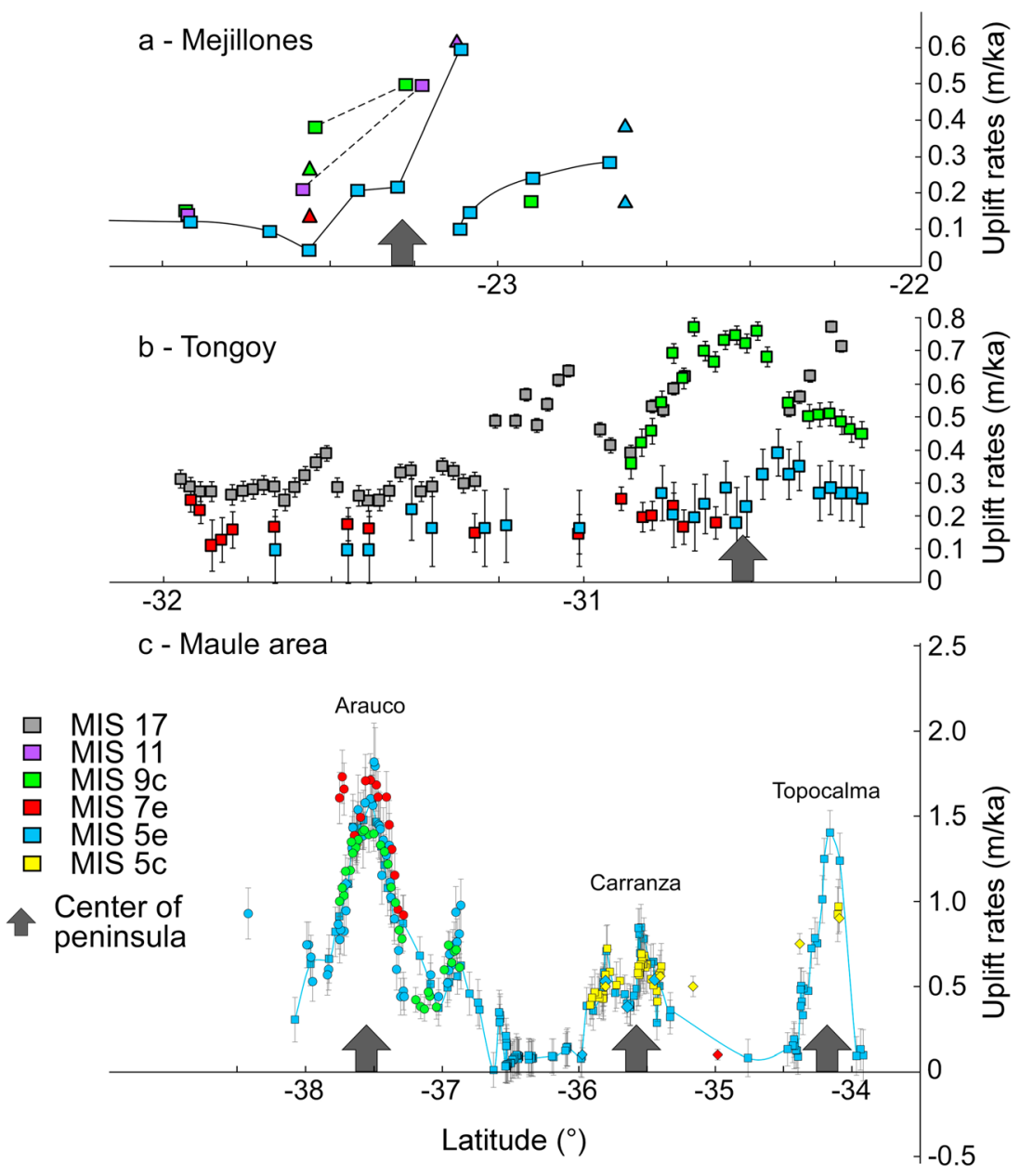

Figure 3. Uplift rates of marine terraces versus latitude in three peninsula areas. Each color corresponds to a marine terrace assigned to a marine isotopic stage (MIS). Zoom views of the three peninsulas illustrate the local N-S variability of marine terrace chronologies showing higher rates closer to the trench (i.e., near the center of the peninsula). (a) Mejillones Peninsula data set after Victor et al. [2011] (squares) and Regard et al. [2010] (triangles), and references therein. (b) Elevations of marine terraces in Tongoy Peninsula extracted from SRTM DEM and ages from Saillard et al. [2009]. (c) Maule area data set: Arauco Peninsula after Melnick et al. [2009] (circles) and Carranza and Topocalma Peninsulas after Jara-Muñoz et al. [2015] (squares). Diamonds correspond to the uplift rates from ${ }^{10}$ Be dating of marine terraces by Melnick et al. [2009]. In this study, we present a new data set, the Tongoy Peninsula data set (Figure 3b), that we compare to two available data sets (to the north (Figure 3a) and to the south (Figure 3c)).

individual terrace levels are more intermingled (less distinct) and often coalesce to form a wide, gently sloping oceanward wave-cut planation surface [Regard et al., 2010]. This typical "rasa" landform called the central Andean rasa lies at a relatively uniform elevation of $\sim 110 \mathrm{~m}$ along the coast from $15^{\circ} \mathrm{S}$ to $33^{\circ} \mathrm{S}$. This relatively simple cliff-face coastal morphology is interrupted by peninsulas such as Mejillones Peninsula, where some of the best preserved marine terraces sequences exist [Regard et al., 2010]. Calculated uplift rates of the central Andean rasa from a review of published chronological data of the central Andean rasa are about $0.25-0.3 \mathrm{~m} / \mathrm{ka}$ [Regard et al., 2010]. This study argues that the whole Andean fore arc, except the peninsulas, has been uplifted relatively continuously for at least $400 \mathrm{ka}$ (MIS 11), after a Pliocene period of quiescence or subsidence, associated with active Quaternary deformation [Hall et al., 2008; Regard et al., 2010; Rodriguez et al., 2013]. From a landscape evolution model simulating coastal erosion and formation of the central Andean rasa, Melnick [2016] estimated Quaternary coastal uplift rates of $0.13 \pm 0.04 \mathrm{~m} / \mathrm{ka}$ along the central Andean fore arc except in the peninsula areas. Coastal uplift rates calculated from marine terrace sequences in peninsula areas are up to about $0.7-0.8 \mathrm{~m} / \mathrm{ka}$ and even locally up to $1.7 \mathrm{~m} / \mathrm{ka}$ (Figure 1) [Saillard et al., 2009, 2011; Jara-Muñoz et al., 2015]. Modeled uplift rates derived by Melnick [2016] for the central Andean rasa are lower than uplift rates calculated by Regard et al. [2010] for the 
same rasa and are much lower than those derived in peninsula areas where the rasa is replaced by distinct marine terraces (Figure 1). As marine terraces are morphotectonic markers of past sea level variations and formed during past sea level highstands, individual marine terraces are assigned to a sea level highstand based on their measured exposure age and associated error (analytical and production rate errors) in the case of terrestrial cosmogenic dating. The age of the corresponding sea level highstand is then used to calculate an uplift rate with the uncertainty coming from the measurement of the terrace elevation and the chronology of the sea level curve [Siddall et al., 2006]. In contrast, Melnick [2016] models the topographic evolution of the coastal region given different uplift scenarios, not based on any direct measurements of uplift or chronometric markers, making this model strongly dependent on the initial topographic modeling of the shelf slope. While the uplift rates generated by this model are generally the same order of magnitude for many coastal regions, it fails to yield the directly measured uplift rates near peninsula areas. Additionally, uplift rates in peninsula areas are (1) variable from one MIS to another and (2) higher at the center of the peninsula than on both flanks (Figure 3). In particular, near Arauco, uplift rates symmetrically vary across the peninsula (Figure 3c). The absence of preserved coastal landforms in some locations suggests that coastal subsidence or very slow uplift could prevail in these regions. The coastal region is subsiding in central Peru [Le Roux et al., 2000; Hampel, 2002] (Figure 1) while very slowly uplifting in the Arica Bend [García et al., 2011] and along the coastal fore arc between the Arica Bend and the Mejillones Peninsula with the slow development of an $\sim 1000 \mathrm{~m}$ high coastal scarp.

Along the Andean margin, marine terraces are preserved where coastal uplift has occurred, either as embayments (built marine terraces) or peninsulas (wave-cut platforms), regardless of the resistance to coastal erosion [Saillard, 2008]. While the trench-coast distance varies along the margin from $\sim 50 \mathrm{~km}$ to more than $200 \mathrm{~km}$, we observe that marine terraces are chiefly present and are being uplifted more rapidly than the rest of the coastal zone where the trench-coast distance is less than $110 \mathrm{~km}$ (Figures 1a and 1b). This pattern suggests a relationship between marine terrace formation and deeper processes related to slab subduction and the downdip extension of the seismogenic zone.

\section{GPS-Derived Interseismic Coupling Model of the Andean Margin}

Interseismic coupling (ISC) is defined as

$$
\mathrm{ISC}=\left(V_{o}-V_{\text {creep }}\right) / V_{0}
$$

where $\left(V_{o}-V_{\text {creep }}\right)$ corresponds to the slip rate deficit and $V_{\text {creep }}$ to the creeping rate on the megathrust during the interseismic period. $V_{o}$ is the long-term slip rate imposed by plate motion, in this case the Nazca/South America convergence rate taken from Kendrick et al. [2003]. An ISC of 0 would indicate a fully creeping megathrust $\left(V_{\text {creep }}=V_{o}\right)$, while an ISC of 1 would correspond to a full locking $\left(V_{\text {creep }}=0\right)$.

To retrieve the interseismic coupling pattern along the megathrust interface from the geodetic measurements, we define a megathrust geometry defined by trench axis on the seafloor and the average local dip of the subducting slab derived from the Slab 1.0 model [Hayes et al., 2012]. The megathrust is meshed into $20 \times 20 \mathrm{~km}^{2}$ square elements embedded in an elastic half-space. The response of a finite fault at a specific location is expressed by summing the contributions of a regular grid of subfaults as

$$
u=\sum \sum S_{\mathrm{ij}}\left[G_{\mathrm{ij}}^{\mathrm{s}} \cos \left(R_{\mathrm{ij}}\right)+\left(G_{\mathrm{ij}}^{d} \sin \left(R_{\mathrm{ij}}\right)\right]\right.
$$

where $u$ is the displacement at an arbitrary station, $i$ is the ith subfault along strike, and $j$ is the $j$ th subfault along dip. $S_{\mathrm{ij}}$ and $R_{\mathrm{ij}}$ are the dislocation slip amplitude and rake angle. The terms $G_{\mathrm{ij}}^{\mathrm{s}}$ and $G_{\mathrm{ij}}^{d}$ are the subfault Green's functions for a unit slip in the strike and dip directions. With this approach, a full representation of the fault response relies on two parameters: the dislocation amplitude and the rake angle that can be inverted by matching the modeled static displacements to the observed GPS measurements. The general forward problem is written as

$$
d=G(m)
$$

where $d$ represents the theoretical data values, $G$ represents the Green function linking the observables to the model, and $m$ are the parameters describing the model. The static displacements are computed following the equation of Okada [1992] with an average shear modulus of $40 \mathrm{GPa}$ and a Poisson coefficient of 0.25 . Using the back slip approach [Savage, 1983], we perform nonlinear inversions of the GPS data based on a simulated 
annealing algorithm to determine the interseismic coupling distribution [Chlieh et al., 2011]. The misfit between the observations and model predictions is computed using a classical weighted root-mean-square of the residuals (wrms) criterion. The cost function to minimize is defined as the summation of the weighted quadratic summation of the misfit to the data (wrms) and another term meant to control the roughness of the back slip distribution:

$$
\text { Cost }=\text { wrms }^{2}+\lambda_{1} D_{c}^{2}
$$

where $D_{c}$ represents the differences in back slip rate between adjacent cells and $\lambda_{1}$ control the roughness through a $L_{1}+L_{2}$ norm [Ji et al., 2002; Chlieh et al., 2014]. We first search for the optimal smoothing factors by varying $\lambda_{1}$ from 0.01 to 10 . Figure $4 \mathrm{~b}$ shows one of the best fitting interseismic models for $\lambda_{1}=0.5$. The average misfit (wrms) for this model is $3.2 \mathrm{~mm} / \mathrm{yr}$. The GPS residuals are oriented in all directions and remain globally within their uncertainties (Figure S1 in the supporting information). A spatial resolution test indicates that the along-strike resolution is relatively high everywhere but drops significantly along-dip especially near the trench. There the boundary condition (no coupling) results in little coupling except where required by the data. The poorly resolved patches appear in coastal areas with sparse GPS measurements or in areas where the trench-coast distance is high, typically higher than $150 \mathrm{~km}$ (Figure S2). To avoid overinterpretation of the interseismic coupling distribution, we indicate the poorly resolved areas with gray shading in the coupling map (Figure $4 \mathrm{~b}$ ). We observe that areas where the coast is closer to the trench tend to have low coupling and are also relatively well resolved and infer that these areas of low coupling are a robust feature of our inversions.

\section{Permanent Coastal Uplift Compared to Interseismic Coupling}

While the depth of the downdip end of the locked zone may vary from margin to margin worldwide [e.g., Dixon and Moore, 2007], in South America, the $110 \mathrm{~km}$ trench-coast distance not only seems to be a threshold distance within which the coastal zone is being uplifted more rapidly and where marine terraces are best preserved. These areas often coincide with peninsulas (Figure 1). But also, the $110 \mathrm{~km}$ trench-coast distance curve seems to mark the downdip end of the locked portion of the Andean seismogenic zone (Figure 4b). We compare Quaternary coastal uplift rates with both the location of major peninsulas and bathymetric features as well as the pattern of interseismic coupling in this fore-arc region (Figure 4). Interseismic coupling varies widely along the coast: it is particularly high (i.e., $>0.6$ ) in central Peru, north of the Pisco-Nazca Peninsula (north of $\sim 14^{\circ} \mathrm{S}$ ), south of the Mejillones Peninsula (between $\sim 24^{\circ} \mathrm{S}$ and $\sim 27^{\circ} \mathrm{S}$ ), and between the Tongoy Peninsula and the Arauco Peninsula (between $\sim 32^{\circ} \mathrm{S}$ and $37^{\circ} \mathrm{S}$ ). In contrast, it is low (i.e., $<0.4$ ) beneath the Pisco-Nazca Peninsula $\left(14-15^{\circ} \mathrm{S}\right)$, Mejillones Peninsula $\left(\sim 23^{\circ} \mathrm{S}\right)$, Punta Choros-Chañaral Peninsula $\left(\sim 29^{\circ} \mathrm{S}\right)$, Tongoy Peninsula $\left(\sim 30^{\circ} \mathrm{S}\right)$, and the southern part of Arauco Peninsula $\left(\sim 37.5^{\circ} \mathrm{S}\right)$ (Figure 4).

In order to investigate further the relationship between coupling and the morphology of the coastline, we compare the trench-coast distance with the lateral variations of the coupling model (Figure 5). The distance between the trench and topography is taken parallel to the measured convergence direction (Euler pole from NUVEL-1A; [DeMets et al., 1994]) because if ongoing subduction of both plates impacts the long-term morphology of the overriding plate, it will be in the direction of convergence. Coupling is integrated downdip in the direction of convergence. Because we anticipate that coupling variations are unrelated to the trench-coast distance at very long $(>500 \mathrm{~km})$ and very short $(<100 \mathrm{~km})$ wavelengths, we band passed the signals between these two values. In particular, the orientation of the coast of southern Peru, between Arica and San Juan de Marcona, is highly oblique to the direction of convergence over $\sim 800 \mathrm{~km}$. Therefore, only for geometrical reasons, this obliquity increases the trench-coast distance as calculated by us (in the direction of convergence) irrespective of the coupling. At the other end of the spectrum, wavelengths shorter than $100 \mathrm{~km}$ likely mirror local structural heterogeneities rather than coupling properties.

Within the prescribed range, the trench-coast distance varies similarly to the integrated coupling along the margin. Indeed, low-coupled areas $(<0.4)$ correspond to peninsulas (negative values match in Figure 5) where the uplift rates are the highest (Figure 4), and highly coupled areas $(>0.6)$ correspond to embayments (positive values match) where the uplift rates are the lowest (Figure 4). This pattern highlights the relationship between the morphology of the coast and interseismic coupling over $\sim 3000 \mathrm{~km}$ along strike. The mean along-strike mismatch distance or lateral shift between the promontories and the location of minimal coupling is $24 \mathrm{~km}$ (standard deviation is $19 \mathrm{~km}$ ), and the lateral shift between the embayments and the 


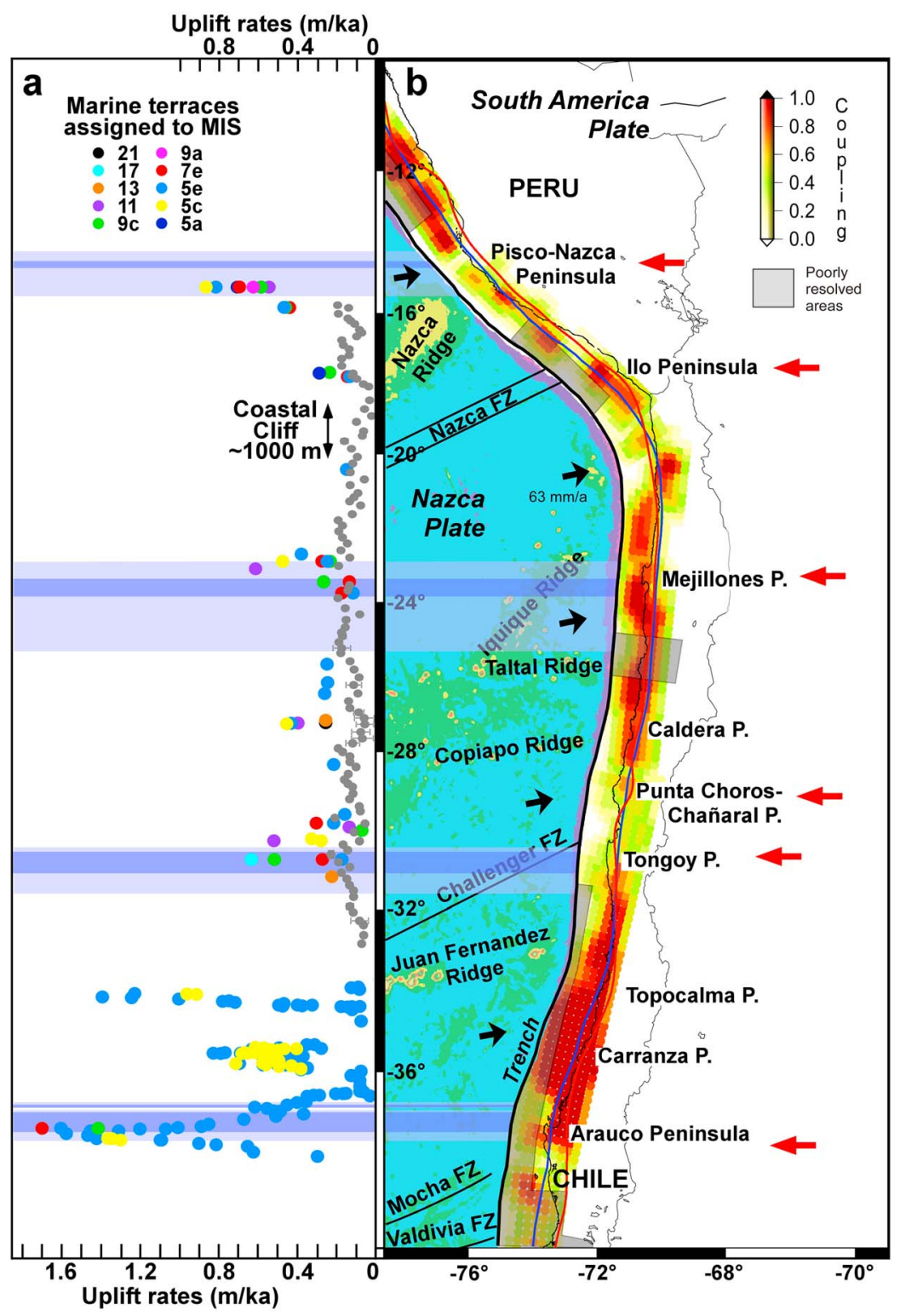

Figure 4. Comparison between the uplift rates, interseismic coupling, major bathymetric features, and peninsulas along the Andean margin $\left(10^{\circ} \mathrm{S}-40^{\circ} \mathrm{S}\right.$ ). (a) Uplift rates of marine terraces reported in the literature (we present the average rate since terrace abandonment; Table S1 in the supporting information [Jara-Muñoz et al., 2015]). Each color corresponds to a marine terrace assigned to a marine isotopic stage (MIS). Gray dots are the uplift rates of the central Andean rasa estimated from a numerical model of landscape evolution [Melnick, 2016]. (b) Major bathymetric features and peninsulas and pattern of interseismic coupling of the Andean margin from GPS data inversion (this study). Gray shaded areas correspond to the areas where the spatial resolution of inversion is low due to the poor density of GPS observations (see text and supporting information for more details). The Peru-Chile trench (thick black line), the coastline (thin black line), and the convergence direction (black arrows) are indicated. We superimposed the curve obtained by shifting the trench geometry eastward by $110 \mathrm{~km}$ (trench-coast distance of $110 \mathrm{~km}$; blue line) with the curve reflecting the $40 \mathrm{~km}$ isodepth of the subducting slab (red line; Slab1.0 from Hayes and Wald [2009]), a depth which corresponds approximately with the downdip end of the locked portion of the Andean seismogenic zone ( $\pm 10 \mathrm{~km})$ [Ruff and Tichelaar, 1996; Khazaradze and Klotz, 2003; Chlieh et al., 2011; Ruegg et al., 2009; Moreno et al., 2011; Métois et al., 2012]. The two curves are spatially similar in the erosive part of the Chile margin (north of $34^{\circ} \mathrm{S}$ ), whereas they diverge along the shallower slab geometry in the accretionary part of the Chile margin (south of $34^{\circ} \mathrm{S}$ ), where the downdip end of the locked zone may be shallower (Figure $4 \mathrm{~b}$ ). Red arrows indicate the low interseismic coupling associated with peninsulas and marine terraces and evidence of aseismic afterslip (after Perfettini et al. [2010] below the Pisco-Nazca Peninsula; Pritchard and Simons [2006], Victor et al. [2011], Shirzaei et al. [2012], Bejar-Pizarro et al. [2013], and Métois et al. [2013] for the Mejillones Peninsula; Métois et al. [2012, 2014] below the Tongoy Peninsula; and Métois et al. [2012] and Lin et al. [2013] for the Arauco Peninsula). FZ: Fracture zone. Horizontal blue bands are the areas where coastline is less than $110 \mathrm{~km}$ (light blue) or $90 \mathrm{~km}$ (dark blue) from the trench (see Figure 1). 


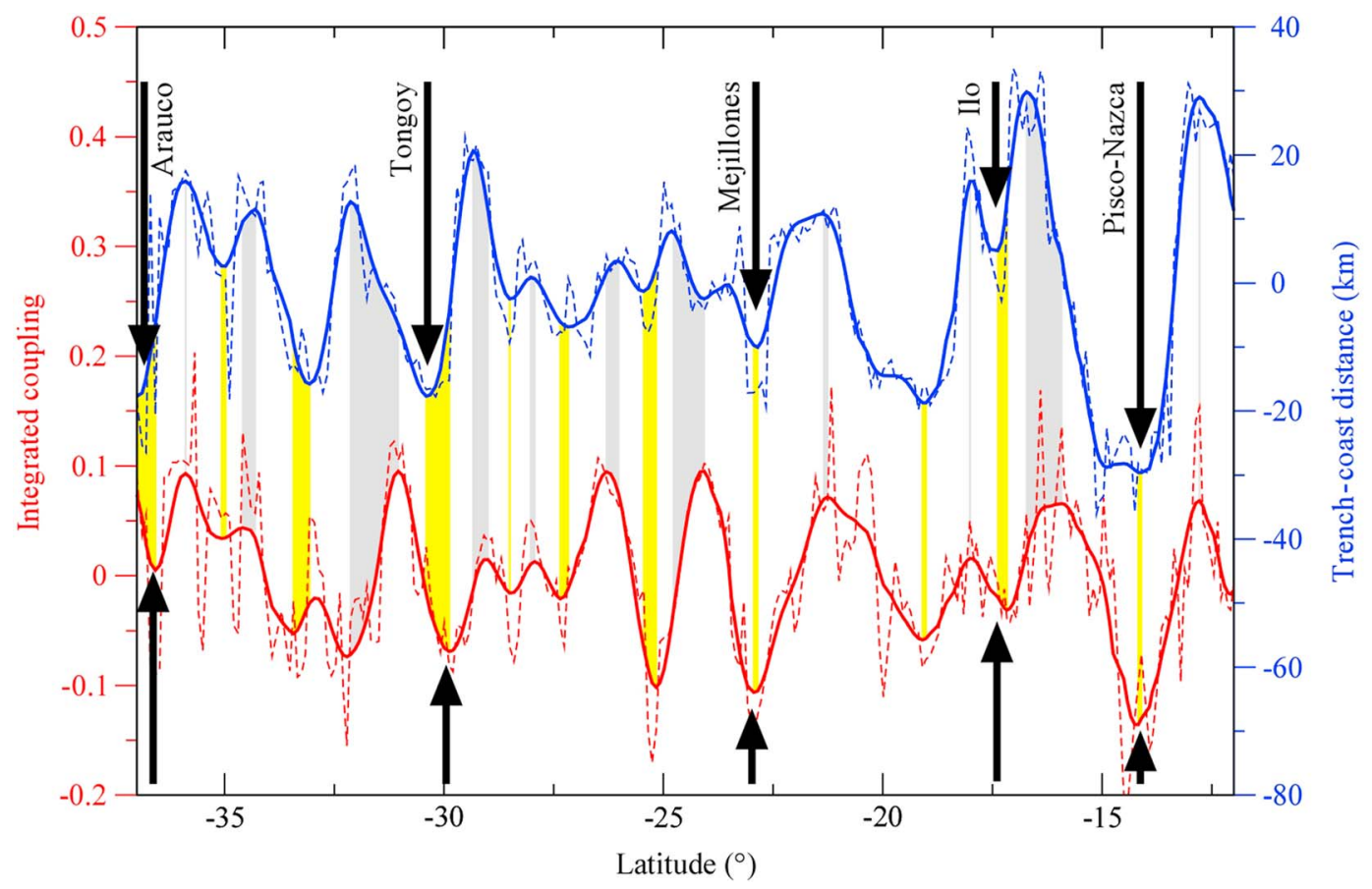

Figure 5. Comparison between short-term, GPS-derived interseismic coupling (red) and trench-coast distances (blue) integrated along the Benioff zone in the convergence direction (Euler pole from NUVEL-1A [DeMets et al., 1994]). Both signals have been band passed for wavelengths ranging between $100 \mathrm{~km}$ and $500 \mathrm{~km}$ (including the mean values and therefore represent the departures from average). Dashed lines show the high-pass filtered signal, leaving all wavelengths shorter than $500 \mathrm{~km}$. Coupling is integrated downdip along the direction of convergence and projected on the slab geometry derived by Hayes et al. [2012]. Black arrows indicate the location of the main peninsulas. Color bars indicate the shortest width pairs (lateral shift) of minima (peninsulas and low coupling areas, yellow; embayments and high coupling areas, gray).

location of maximal coupling is $37 \mathrm{~km}$ (standard deviation is $41 \mathrm{~km}$ ). Because these lateral shifts are much smaller than the lowest admitted wavelength (100 km), it gives us confidence in our correlation between the trench-coast distance and the coupling.

We also considered the interseismic coupling model of Métois et al. [2016], which covers a fraction of our study area (a shorter latitudinal extent; $18^{\circ} \mathrm{S}$ to $36^{\circ} \mathrm{S}$ ), to test the robustness of our results. Their model also shows a clear correlation between trench-coast distance and integrated coupling (Figure S3); the lateral shift between the promontories and the location of minimal coupling is about $57 \mathrm{~km}$ (standard deviation is $45 \mathrm{~km}$ ), and the lateral shift between the embayments and the location of maximal coupling is about $41 \mathrm{~km}$ (standard deviation is $28 \mathrm{~km}$ ).

\section{Along-Strike Seismic Segmentation of the Andean Margin}

To illustrate the spatial pattern of seismic ruptures and rupture limits, we have compiled the rupture extents of major historical megathrust earthquakes from central Peru to southern Chile for the past 500 years (Figure 1c; see Table S1 for references). We observe that $M_{w} \geq 8.5$ earthquakes are confined to latitudes north of $20^{\circ} \mathrm{S}$ and south of $31^{\circ} \mathrm{S}$. In contrast, $M_{w} \leq 7.5$ earthquakes are dominant at latitudes between $18^{\circ} \mathrm{S}$ and $27^{\circ} \mathrm{S}$ and particularly in the Arica Bend region (Figure 1c). The peninsulas of Pisco-Nazca, Ilo, Mejillones, Tongoy, and Arauco seem to mark the end points of a number of adjacent ruptures, which suggests to us that these peninsulas constitute persistent barriers to rupture propagation along the megathrust. For instance, Arauco Peninsula is at the northern boundary of the 1960 southern Chile event; the 1575, 1737, and 1837 events; and at the southern limit of the 1570 and 1835 events [Lomnitz, 1970, 2004; Cisternas et al., 2005]. The Mejillones Peninsula coincides with the northern limit of the 1995 Antofagasta earthquake and with the southern limit of the 2007 Tocopilla earthquake [Pritchard et al., 2002; Delouis et al., 2009; Loveless et al., 2010; Schurr et al., 2012] and probably with the southern limit of the 1877 lquique earthquake [Kausel and Campos, 1992]. Similarly, numerous subduction earthquakes 

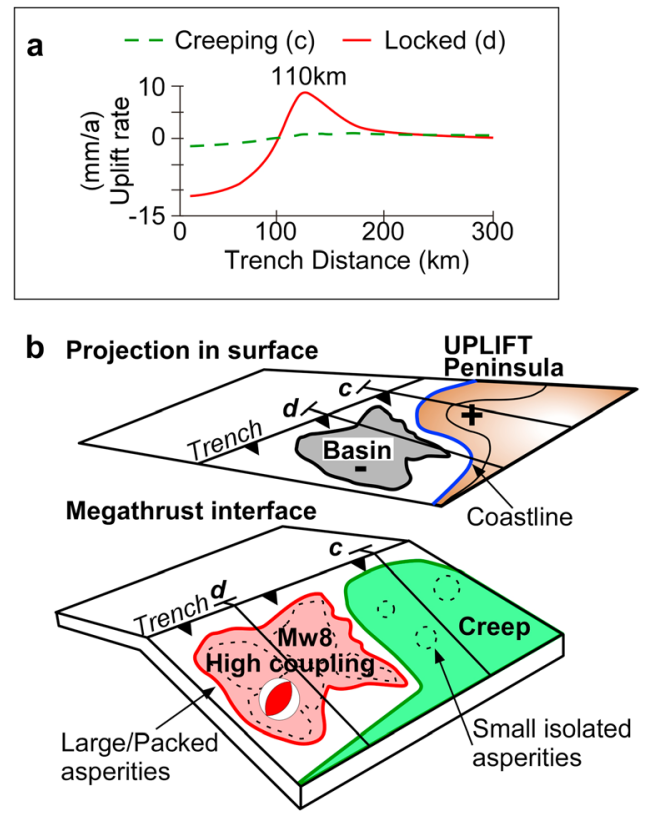

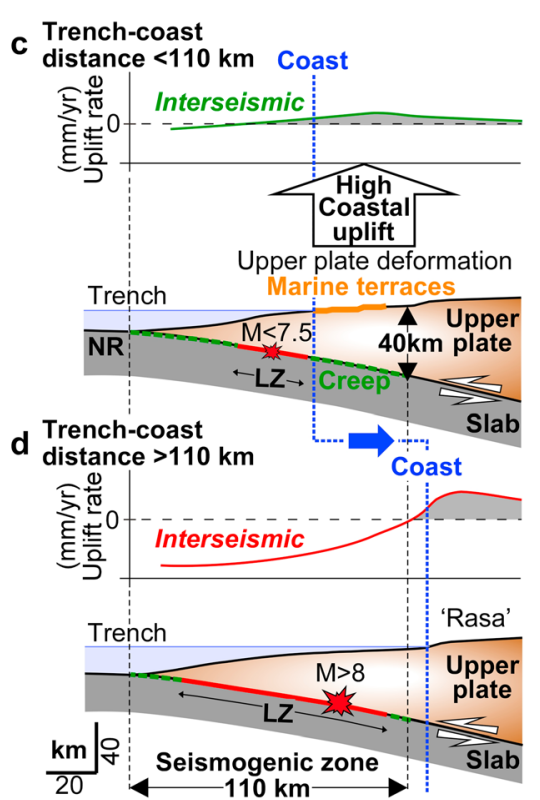

Figure 6. Conceptual model proposing a link between coastal deformation (building permanent uplift producing the marine terraces distribution we observe) and seismogenic behavior of the megathrust assuming an elastoplastic model of the Earth. (a) Theoretical fore-arc deformation in cases of aseismic slip and assuming that part of plate interface is fully locked (i.e., down to a depth of $40 \mathrm{~km}$ ) during the interseismic period (modified from Chlieh et al. [2008]). The $40 \mathrm{~km}$ downdip isodepth on the slab corresponds to a $110 \mathrm{~km}$ horizontal width of the seismogenic zone in plan view. (b) The 3-D sketch illustrating the proposed relationship between interseismic coupling and coastal morphology. Where the subduction interface is highly coupled during the interseismic period, there is negligible long-term coastal uplift but subsidence (minus sign). Highly coupled zone corresponds to fore-arc basin and seismic rupture zone. In contrast, peninsulas and promontories correspond to zones with low interseismic coupling (creeping zone), coastal uplift (plus sign), and seismic barrier. (c, top) Fore-arc deformation (uplift in gray area) occurring in case of mostly aseismic slip on the subduction interface, as the locked zone is narrower and (bottom) simplified cross section of a narrow locked zone and aseismic asperities exemplifying observed onshore long-term deformation above a creeping segment (red star: $M_{w}<7.5$ megathrust earthquakes such as Nazca 1996). Marine terrace sequences associated to high coastal uplift rates are well preserved, where the coastline lies above an aseismic patch on the subduction zone, i.e., within the defined threshold trench-coast distance of $110 \mathrm{~km}$. (d, top) Fore-arc interseismic uplift (gray area) in a fully coupled context and (bottom) simplified cross section of a subduction margin and its wide seismogenic locked zone in red (red star: $M_{w}>8$ megathrust earthquakes such as Lima 1746) with low coastal uplift rates and development of rasa morphology. LZ: locked zone. The locations of the cross sections in Figures $6 \mathrm{c}$ and $6 \mathrm{~d}$ are indicated.

have stopped north or south of llo Peninsula, such as the 1604, 1687, 1833, and 2001 events, although some ruptures have crossed it, such as the 1784 and 1868 events [Dorbath et al., 1990; Robinson et al., 2006; Audin et al., 2008]. The Pisco-Nazca Peninsula coincides with the 1604, 1784, 1868, 1974, 2001, and 2007 rupture limits, while the 1687 event seems to have crossed the entire peninsula [Beck and Nishenko, 1990; Spence et al., 1999; Giovanni et al., 2002; Perfettini et al., 2010]. Finally, the Tongoy Peninsula correlates well with the rupture limits of at least the 1730, 1819, 1922, 1943, and 2015 earthquakes. However, such a correlation between rupture limits and peninsula location is less clear for the Caldera and Punta Choros-Chañaral Peninsulas (Figures 1c and 1d).

\section{On the Relationships Between Seismic Segmentation, Long-Term Upper Plate Deformation, and Interseismic Coupling}

A well-established view of the seismic cycle along a megathrust is that the fore-arc wedge subsides offshore and uplifts onshore during the interseismic period as it is compressed and dragged down by the coupled, subducting lower plate. This pattern can be modeled based on the theory of dislocations embedded in an elastic half-space [Savage, 1983] (left inset of Figure 6) and is, to first order, the pattern observed along most subduction zones, indicating that the plate interface is fully or partially locked down to a typical depth of $40 \pm 10 \mathrm{~km}$ [Ruff and Tichelaar, 1996; Khazaradze and Klotz, 2003; Ruegg et al., 2009; Chlieh et al., 2011; Moreno et al., 2011; 
Métois et al., 2012]. Implicit to this standard model, interseismic fore-arc deformation is elastic and is recovered during large interplate earthquakes [Savage, 1983]. As a result, there is no long-term deformation of the fore arc. This standard model agrees to first order with the observation that long-term uplift or subsidence rates are generally 1 order of magnitude smaller than interseismic rates [Briggs et al., 2008]. One simple view of how permanent fore-arc deformation might develop is to consider that a fraction of interseismic strain might actually be nonrecoverable during coseismic release due to viscous or plastic deformation [e.g., Marshall and Anderson, 1995; von Huene and Klaeschen, 1999]. Indeed, Van Dinther et al. [2013] showed from numerical models that $\sim 5 \%$ of total convergence is nonrecoverable and converted to permanent deformation of the upper plate. If we consider a nonrecoverable fraction of interseismic strain related to plate deformation and assume a simple case that the lateral variation in the pattern of interseismic coupling is negligible along the margin, we expect subsidence to accumulate seaward of the downdip end of the locked fault zone, hence mostly offshore. Similarly, uplift should accumulate onshore. This would explain the general coincidence of the coastline with the downdip end of the locked fault zone. However, the high uplift rates observed in the areas of peninsulas and promontories do not fit this pattern, as these areas lie where subsidence, not uplift, would be expected (Figure 4). For this explanation to hold, one would need the downdip edge of the locked zone to occur at a shallower depth below peninsulas and promontory areas than along other portions of the margin.

Under most of the peninsulas and promontories, slip along the megathrust seems to be mostly aseismic (i.e., Arauco, Tongoy, Mejillones, Ilo, and Pisco-Nazca Peninsulas; Figures 4 and 5), a pattern visible from postseismic and interseismic observations in the Pisco-Nazca area [Perfettini et al., 2010; Remy et al., 2016]. Similarly, geodetic observations show low interseismic coupling and aseismic deformation below the Arauco Peninsula [Métois et al., 2012] as we observe in our model. Further, aseismic slip below the Arauco Peninsula is consistent with observed postseismic deformation following the Maule earthquake [Lin et al., 2013]. Note however that the interseismic coupling model of Moreno et al. [2011], which included a correction for viscoelastic relaxation following the 1960 Chile earthquake, does not show low coupling beneath the Arauco Peninsula. It could therefore be argued that long-term uplift of the Arauco Peninsula is independent from the megathrust seismic cycle. For example, Melnick et al. [2009] proposed that the formation of this Peninsula is related to the growth of a margin-normal anticline driven by north-south compression due to motion of the fore-arc sliver against a buttress characterized by the deep-seated reverse Lanalhue Fault.

Near the Tongoy Peninsula, Métois et al. [2012, 2014, 2016] indicates low coupling throughout the fore-arc region, suggesting that the megathrust aseismically slips in this particular region as well (Figure 4). There is also evidence for aseismic slip below the Mejillones Peninsula following the 1995 Antofagasta earthquake [Pritchard and Simons, 2006; Victor et al., 2011] and during the interseismic period [Victor et al., 2011; BejarPizarro et al., 2013; Métois et al., 2013; Li et al., 2015; Cortès-Aranda et al., 2015]. For both 1995 Antofagasta and 2007 Tocopilla earthquake sequences, Schurr et al. [2012] demonstrate that aftershocks concentrate in the conditionally stable region (transition zone between seismic and aseismic slip [e.g., Scholz, 1998]), whereas the maximum interseismic slip deficit and coseismic slip occur in the unstable region. The combined Antofagasta and Tocopilla aftershock series skirt around Mejillones Peninsula and indicate that the downdip end of the seismogenic zone is shallow beneath Mejillones Peninsula [Schurr et al., 2012].

Some observations from the Maule earthquake area also support the hypothesis that anelastic strain (permanent deformation) accumulates more rapidly over creeping portions of the plate interface. Based on the critical taper theory, Cubas et al. [2013] showed that the rupture area of the Maule earthquake (and possibly of the 1960 Chile earthquake), which was mostly locked in the interseismic period, coincides with a stable portion of the fore-arc wedge. In contrast, the areas that surround the earthquake rupture zone coincide with a critical portion of the fore-arc wedge and with aseismic afterslip [Lin et al., 2013; Cubas et al., 2013]. This relationship is consistent with various lines of evidence for active deformation of the fore arc, in particular the Arauco Peninsula area, which seems to have arrested the Maule earthquake's rupture to the south [Cubas et al., 2013]. These observations suggest that megathrust seismic rupture is inhibited when propagating beneath a wedge in critical mechanical state and that critical areas are associated with active deformation of the fore arc and correlate well with aseismic creep on the megathrust [Cubas et al., 2013] (Figure 4).

A similar correlation between the mode of slip, creeping or locked, along the plate interface and permanent deformation of the upper plate has been observed in analogue models of elastoplastic seismic cycles [Rosenau and Oncken, 2009]. Rosenau and Oncken [2009] demonstrated that shortening within 
the wedge localizes over multiple seismic cycles at the periphery of the stick-slip (locked) zone due to coseismic compression at the updip limit and interseismic compression at the downdip limit. Over geological timescales (100 ka-Ma), zones of permanent uplift will therefore localize at the periphery of stable fore-arc basins, which correlate spatially (and causally) with the frictionally unstable areas along the plate interface. If the downdip end of the locked zone is spatially stable over many seismic cycles, and a few percent of the interseismic shortening accumulates as permanent, upper plate thickening would suffice to reconcile observed long-term coastal uplift rates and thus contribute to coastal uplift over geologic timescales (100 ka-Ma) [Schurr et al., 2012].

There is evidence that some fraction of interseismic strain is permanent, in particular at the edges of the locked zones. In New Zealand, margin-normal shortening in the upper plate of the central Hikurangi subduction zone accounts for about $6-19 \%$ of the total plate convergence over the last 5 Myr, while on average more than $80 \%$ of convergence has been accommodated by margin-normal slip on the subduction interface [Nicol and Beavan, 2003]. They argue that high strain in the upper plate is concentrated at the downdip end of the locked portion of the Hikurangi megathrust. Similarly, Schurr et al. [2012] suggest that upper plate compression related to the downdip locking gradient in the transition zone is responsible for long-term permanent uplift of the coastline in the Mejillones Peninsula region. In another context, the high topography of the Himalaya correlates with the downdip edge of the locked portion of the Himalayan megathrust and correlates with interseismic uplift, suggesting that topography dominantly builds in the interseismic period at the edge of locked zones [e.g., Stevens and Avouac, 2015].

Melnick [2016] argues that coastal uplift results from incremental coseismic deformation associated with moderate earthquakes along the downdip edge of the locked portion of the megathrust. This model has some merit but it is not established that (1) these earthquakes are the only contributors to coastal uplift and (2) that they are slip events positioned on the megathrust. For comparison, in the Himalayan context, small earthquakes triggered by stress buildup in the interseismic period occur beneath the steep front of the high range, but these events are not on the Himalayan megathrust [e.g., Cattin and Avouac, 2000]. It is possible that deformation and uplift of the peninsulas along the South American coastline are associated with some seismicity, but the seismicity could be distributed along smaller faults within the fore arc rather than being slip events along the megathrust. Given the evidence for aseismic deformation of the fore arc in peninsula areas [Victor et al., 2011; Shirzaei et al., 2012], we argue that creep along the megathrust could drive anelastic deformation and hence uplift of the fore arc in the peninsula areas. Peninsulas are nonetheless dragged down in the interseismic period due to locking of the adjacent segment and are uplifted as these adjacent segments ruptured (Figure 6). The net effect is long-term uplift due to the fraction of anelastic thickening of the fore arc that accumulates between large megathrust events possibly in the postseismic period following these events.

\section{Seismic Segmentation and Relation to Frictional Properties of the Megathrust}

Some of the persistent barriers along the coast of South America might be related to subducting ridges or fracture zones [e.g., Sparkes et al., 2010; Robinson et al., 2006] but clearly not all, in particular not for the Ilo, Mejillones, and Arauco areas. Subducting ridges and fracture zones have both been observed to correlate with regions of aseismic slip such as beneath the Pisco-Nazca Peninsula where the Nazca Ridge is subducting [Perfettini et al., 2010; Remy et al., 2016], as well as beneath the Batu Islands of Indonesia where the Investigator Fracture Zone is subducting [Chlieh et al., 2008]. Conversely, there are additional examples of aseismic slip zones clearly unrelated to subducting ridges along the Hikurangi subduction margin near the Mahia Peninsula, New Zealand [Wallace et al., 2012], and in northern Peru [Nocquet et al., 2014]. A $1000 \mathrm{~km}$ long section of the plate interface in northern Peru and southern Ecuador slips predominantly aseismically, a behavior that contrasts with the highly seismic neighboring segments [Nocquet et al., 2014]. We therefore conclude that while fracture zones and subducting aseismic ridges may be a factor of megathrust segmentation, other factors must play a role.

Downdip variations of frictional properties, due to lithology and temperature changes, are thought to explain downdip variations of the mode of slip [e.g., Scholz, 1998; Hyndman et al., 1997]. This model makes a distinction between areas that are rate strengthening, which should predominantly creep aseismically and which should tend to arrest the propagation of seismic ruptures, and areas that are rate weakening, within which 
earthquakes can nucleate and rupture can propagate through. The correlation between the pattern of interseismic coupling and megathrust seismic ruptures suggests that a similar framework might also explain along strike segmentation: rate-strengthening patches if they are large enough or strongly rate dependent can systematically arrest seismic rupture and appear as permanent barriers, while rate-weakening patches tend to produce stick-slip behavior with long interseismic periods of locking alternating with transient slip events [Kaneko et al., 2010]. We argue that this framework can also provide an explanation for the correlation with permanent deformation of the fore arc. Where slip is mostly seismic, shear stresses on the megathrust are limited by dynamic friction. At seismic sliding rates, various weakening mechanisms can result in a very low dynamic friction [e.g., Di Toro et al., 2011; Kanamori and Brodsky, 2004]. After a seismic event, the shear stress drops to the dynamic level. In a locked area, the stress will build up at slow rate during the interseismic period. Shear stresses can thus remain low, close to the dynamic friction. Slip along a patch of such low stress can occur when transient stress increases at the front of a propagating rupture (associated with the seismic waves generated by the rupture itself) to a point that is large enough to bring the fault to failure. For example, Cubas et al. [2015] provides a discussion of this effect based on dynamic simulations. As a result, a portion of the fore arc overlying the seismogenic zone of the megathrust might be stable and will therefore not deform internally. Physically, this may look like a wedge with a low seaward slope or possibly a fore-arc basin [Fuller et al., 2006]. In contrast, creeping areas (with low interseismic coupling) governed by rate-strengthening friction are expected to operate under relatively higher stresses [Cubas et al., 2013; Gao and Wang, 2014; Wang and Bilek, 2014]. However, a high stress level may not be required if creep is due to conditionally stable slip on a rate-weakening patch with high pore pressure as proposed for the Arauco Peninsula by Moreno et al. [2014].

\section{Conclusions}

From our analysis of the fore-arc morphology along the South American active margin, we observe that the peninsulas, where the coastline is closer than $\sim 110 \mathrm{~km}$ from the trench, are systematically uplifted at higher rates than the surrounding regions $(>0.4 \mathrm{~m} / \mathrm{ka}$ ). These peninsulas are features related to dynamic processes, stable over several $100 \mathrm{kyr}$, and reflect anelastic (permanent) deformation of the fore arc (across strike) that accumulates over time. We also observed that peninsulas tend to form above aseismically sliding areas. Along strike, most of the peninsulas have a "barrier effect" in that they approximately coincide with the bounds of the historical rupture zones on the megathrust. This correlation suggests that these areas prevent elastic strain buildup and inhibit lateral seismic rupture propagation. Correlation between the location of these regions across and along strike of convergence and the long-term morphology of the subduction margin suggests that the barrier effect might be due to rheology, namely, rate-strengthening friction, although geometric effects might also play a secondary role. Higher shear stress along creeping segments of the megathrust than along segments dominated by recurring large earthquakes would favor more rapid viscoplastic (permanent) deformation of the fore arc and thus uplift. Marine terrace sequences attest to frictional properties along the megathrust persisting for million-year time scales. Peninsulas are the surface expression of large subduction earthquakes segment boundaries and show evidence for their stability over multiple seismic cycles. Varying uplift rates (increasing or decreasing) could be related to the transience of the frictional properties and lateral limits of the seismogenic asperities. If so, the initiation of a change in Pleistocene uplift rates could indicate a change in plate interface characteristics over time. Our analysis suggests that spatial variations of the seismogenic behavior along the Andean megathrust are stationary and reflect in the morphotectonic features of the fore arc over geologic timescales.

Acknowledgments

This research project was led thanks to support of the Institut de Recherche pour le Développement. We thank T. Schildgen and two anonymous reviewers for their constructive and critical comments of this manuscript. All data for this paper are properly cited and referred to in the reference list and available by contacting the corresponding author (marianne.saillard@ird fr). We would like to dedicate this work to the memory of Luc Ortlieb.

\section{References}

Altamimi, Z., X. Collilieux, and L. Métivier (2011), ITRF2008: An improved solution of the International Terrestrial Reference Frame, J. Geod., 85(8), 457-473.

Ammon, J. C., et al. (2005), Rupture process of the 2004 Sumatra-Andaman earthquake, Science, 308, $1133-1139$.

Ando, M. (1975), Source mechanisms and tectonic significance of historical earthquakes along the Nankai Trough, Japan, Tectonophysics, 27, 119-140.

Ashtari Jafari, M. (2015), The March-April 2014 sequence of earthquakes in north Chile, J. South Am. Earth Sci., 62, $125-135$.

Audin, L., P. Lacan, H. Tavera, and F. Bondoux (2008), Upper plate deformation and seismic barrier in front of Nazca subduction zone: The Chololo Fault System and active tectonics along the Coastal Cordillera, southern Peru, Tectonophysics, 459, 174-185, doi:10.1016/j.tecto.2007.11.070.

Avouac, J.-P. (2015), From geodetic imaging of seismic and aseismic fault slip to dynamic modeling of the seismic cycle, Annu. Rev. Earth Planet. Sci., 43(43), 233-271.

Barrientos, S. (2007), Earthquakes in Chile, in The Geology of Chile, edited by T. Moreno and W. Gibbons, pp. 263-287, Geol. Soc. of London, London. 
Beck, S., S. Barrientos, E. Kausel, and M. Reyes (1998), Source characteristics of historic earthquakes along the central Chile subduction zone, J. South Am. Earth Sci., 11, 115-129.

Beck, S. L., and S. P. Nishenko (1990), Variations in the mode of great earthquake rupture along the central Peru subduction zone, Geophys. Res. Lett., 17, 1969-1972, doi:10.1029/GL017i011p01969.

Bejar-Pizarro, M., A. Socquet, R. Armijo, D. Carrizo, J. Genrich, and M. Simons (2013), Andean structural control on interseismic coupling in the north Chile subduction zone, Nat. Geosci., 6, 462-467, doi:10.1038/NGEO1802.

Bevis, M., E. Kendrick, R. Smalley Jr., B. Brooks, R. Allmendinger, and B. Isacks (2001), On the strength of interplate coupling and the rate of back arc convergence in the central Andes: An analysis of the interseismic velocity field, Geochem. Geophys. Geosyst., 2(11), 1067, doi:10.1029/2001GC000198.

Bilek, S. (2010), Seismicity along the South American subduction zone: Review of large earthquakes, tsunamis, and subduction zone complexity, Tectonophysics, 495, 2-14.

Bloom, A. L. (1998), Geomorphology: A Systematic Analysis of Late Cenozoic Landforms, 3rd, pp. 482, Prentice Hall, Upper Saddle River, N. J., ISBN 0-13-505496-6.

Briggs, R. W., K. Sieh, W. H. Amidon, J. Galetzka, D. Prayudi, I. Suprihanto, N. Sastra, B. Suwargadi, D. Natawidjaja, and T. G. Farr (2008), Persistent elastic behavior above a megathrust rupture patch: Nias island, West Sumatra, J. Geophys. Res., 113, B12406, doi:10.1029/2008JB005684.

Brooks, B. A., et al. (2011), Orogenic-wedge deformation and potential for great earthquakes in the central Andean backarc, Nat. Geosci., 4(6), 380-383.

Burgmann, R., M. G. Kogan, G. M. Steblov, G. Hilley, V. E. Levin, and E. Apel (2005), Interseismic coupling and asperity distribution along the Kamchatka subduction zone, J. Geophys. Res., 110, B07405, doi:10.1029/2005JB003648.

Cattin, R., and J. P. Avouac (2000), Modeling mountain building and the seismic cycle in the Himalaya of Nepal, J. Geophys. Res., 105, 13,389-13,407, doi:10.1029/2000JB900032

Chappell, J., and N. J. Shackleton (1986), Oxygen isotopes and sea level, Nature, 324, 137-140.

Chlieh, M., J. B. de Chabalier, J. C. Ruegg, R. Armijo, R. Dmowska, J. Campos, and K. L. Feigl (2004), Crustal deformation and fault slip during the seismic cycle in the north Chile subduction zone, from GPS and InSAR observations, Geophys. J. Int., 158, 695-711, doi:10.1111/j.1365246X.2004.02326.X.

Chlieh, M., J.-P. Avouac, K. Sieh, D. H. Natawidjaja, and J. Galetzka (2008), Heterogeneous coupling of the Sumatran megathrust constrained by geodetic and paleogeodetic measurements, J. Geophys. Res., 113, B05305, doi:10.1029/2007JB004981.

Chlieh, M., H. Perfettini, H. Tavera, J.-P. Avouac, D. Remy, J.-M. Nocquet, F. Rolandone, F. Bondoux, G. Gabalda, and S. Bonvalot (2011), Interseismic coupling and seismic potential along the central Andes subduction zone, J. Geophys. Res., 116, B12405, doi:10.1029/ $2010 J B 008166$.

Chlieh, M., et al. (2014), Distribution of discrete seismic asperities and aseismic slip along the Ecuadorian megathrust, Earth Planet. Sci. Lett., 400, 292-301, doi:10.1016/j.epsl.2014.05.027.

Cisternas, M., et al. (2005), Predecessors of the giant 1960 Chile earthquake, Nature, 437, 404-407.

Comte, D., et al. (1986), The 1985 central Chile earthquake: A repeat of previous great earthquakes in the region?, Science, 233, 449-453.

Comte, D., et al. (2002), Seismicity and stress distribution in the Copiapo, northern Chile subduction zone using combined on- and off-shore seismic observations, Phys. Earth Planet. Inter., 132, 197-217.

Cortès, A. J., L. G. González, S. A. Binnie, R. Ruth, S. P. H. T. Freeman, and G. Vargas (2012), Paleoseismology of the Mejillones Fault, northern Chile: Insights from cosmogenic ${ }^{10} \mathrm{Be}$ and optically stimulated luminescence determinations, Tectonics, 31, TC2017, doi:10.1029/ 2011 TC002877.

Cortès-Aranda, J., G. Gonzalez, D. Remy, and J. Martinod (2015), Normal upper plate fault reactivation in northern Chile and the subduction earthquake cycle: From geological observations and static Coulomb failure stress (CFS) change, Tectonophysics, 639, 118-131, doi:10.1016/j.tecto.2014.11.019.

Cubas, N., J.-P. Avouac, P. Souloumiac, and Y. Leroy (2013), Megathrust friction determined from mechanical analysis of the forearc in the Maule earthquake area, Earth Planet. Sci. Lett., 381, 92-103, doi:10.1016/j.epsl.2013.07.037.

Cubas, N., N. Lapusta, J.-P. Avouac, and H. Perfettini (2015), Numerical modeling of long-term earthquake sequences on the NE Japan megathrust: Comparison with observations and implications for fault friction, Earth Planet. Sci. Lett., 419, 187-198.

Delouis, B., et al. (1997), The $M_{w}=8.0$ Antofagasta (northern Chile) earthquake of July 30 1995: A precursor to the end of the large 1877 gap, Bull. Seism. Soc. Am., 87, 427-445.

Delouis, B., M. Pardo, D. Legrand, and T. Monfret (2009), The $M_{w} 7.7$ Tocopilla earthquake of 14 November 2007 at the southern edge of the northern Chile seismic gap: Rupture in the deep part of the coupled plate interface, Bull. Seismol. Soc. Am., 99, -87, doi:10.1785/ 0120080192.

DeMets, C., R. G. Gordon, D. F. Argus, and S. Stein (1994), Effect of recent revisions to the geomagnetic reversal time scale on estimate of current plate motions, Geophys. Res. Lett., 21, 2191-2194, doi:10.1029/94GL02118.

Di Toro, G., R. Han, T. Hirose, N. De Paola, S. Nielsen, K. Mizoguchi, F. Ferri, M. Cocco, and T. Shimamoto (2011), Fault lubrication during earthquakes, Nature, $471(7339)$.

Dixon, T. H., and J. C. Moore (2007), The Seismogenic Zone of Subduction Thrust Faults, pp. 680, Columbia Univ. Press, New York.

Dorbath, L., A. Cisternas, and C. Dorbath (1990), Assessment of the size of large and great historical earthquakes in Peru, Bull. Seismolog. Soc. Am., 80, 551-576.

Fuller, C. W., S. D. Willet, and M. T. Brandon (2006), Formation of forearc basins and their influence on subduction zone earthquakes, Geology $34(2), 65-68$.

Gagnon, K., C. D. Chadwell, and E. Norabuena (2005), Measuring the onset of locking in the Peru-Chile trench with GPS and acoustic measurements, Nature, 434(7030), 205-208, doi:10.1038/nature03412.

Gao, X., and K. L. Wang (2014), Strength of stick-slip and creeping subduction megathrusts from heat flow observations, Science, 345(6200), 1038-1041.

García, M., R. Riquelme, M. Farías, G. Hérail, and R. Charrier (2011), Late Miocene-Holocene canyon incision in the western Altiplano, northern Chile: Tectonic or climatic forcing?, J. Geol. Soc., 168, 1047-1060, doi:10.1144/0016-76492010-134.

Giovanni, M., S. Beck, and L. Wagner (2002), The June 23, 2001 Peru earthquake and the southern Peru subduction zone, Geophys. Res. Lett., 29(21), 2018, doi:10.1029/2002GL015774.

Goy, J. L., J. Macharé, L. Ortlieb, and C. Zazo (1992), Quaternary shorelines in southern Peru: A record of global sea level fluctuations and tectonic uplift in Chala Bay, Quat. Int., 15, 99-112.

Hall, S. R., D. L. Farber, L. Audin, R. C. Finkel, and A.-S. Mériaux (2008), Geochronology of pediment surfaces in southern Peru: Implications for Quaternary deformation of the Andean forearc, Tectonophysics, 459, 186-205, doi:10.1016/j.tecto.2007.11.073. 
Hampel, A. (2002), The migration history of the Nazca Ridge along the Peruvian active margin: A re-evaluation, Earth Planet. Sci. Lett., 203, $665-679$.

Hayes, G. P., and D. J. Wald (2009), Developing framework to constrain the geometry of the seismic rupture plane on subduction interfaces a priori-A probabilistic approach, Geophys. J. Int., 176, 951-964, doi:10.1111/j.1365-246X.2008.04035.X.

Hayes, G. P., D. J. Wald, and R. L. Johnson (2012), Slab1.0: A three-dimensional model of global subduction zone geometries, J. Geophys. Res., 117, B01302, doi:10.1029/2011JB008524.

Hetland, E. A., and M. Simons (2010), Post-seismic and interseismic fault creep II: Transient creep and interseismic stress shadows on megathrusts, Geophys. J. Int., 181, 99-112.

Hsu, J. T. (1992), Quaternary uplift of the Peruvian coast related to the subduction of the Nazca Ridge: 13.5 to 15.6 degrees south latitude, Quat. Int., 15-16, 87-97.

Hyndman, R. D., M. Yamano, and D. A. Oleskevich (1997), The seismogenic zone of subduction thrust faults, Island Arc, 6(3), 244-260.

Jara-Muñoz, J., D. Melnick, D. Brill, and M. R. Strecker (2015), Segmentation of the 2010 Maule Chile earthquake rupture from a joint analysis of uplifted marine terraces and seismic-cycle deformation patterns, Quat. Sci. Rev., 113, 171-192, doi:10.1016/j.quascirev.2015.01.005.

Ji, C., D. Wald, and D. V. Helmberger (2002), Source description of the 1999 Hector Mine, California earthquake, Part I: Wavelet domain inversion theory and resolution analysis, Bull. Seismol. Soc. Am., 92(4), 1192-1207, doi:10.1785/0120000916.

Kanamori, H., and E. E. Brodsky (2004), The physics of earthquakes, Rep. Prog. Phys., 67, 1429-1496.

Kanamori, H., and K. C. McNally (1982), Variable rupture mode of the subduction zone along the Ecuador-Colombia coast, Bull. Seismol. Soc Am., 72(4), 1241-1253.

Kaneko, Y., J. P. Avouac, and N. Lapusta (2010), Towards inferring earthquake patterns from geodetic observations of interseismic coupling, Nat. Geosci., 3, 363-369.

Kausel, E., and J. Campos (1992), The $M_{s}=8$ tensional earthquake of December 9, 1950 of northern Chile and its relation to the seismic potential of the region, Phys. Earth. Planet. Int., 72, 220-235.

Kelleher, J. (1972), Rupture zones of large South American earthquakes and some predictions, J. Geophys. Res., 77, 2087-2103, doi:10.1029/ JB077i011p02087.

Kendrick, E., M. Bevis, J. R. Smalley, B. Brooks, R. B. Vargas, E. Lauria, and L. P. Souto Fortes (2003), The Nazca-South America Euler vector and its rate of change, J. South Am. Earth Sci., 16(2), 125-131, doi:10.1016/S0895-9811(1003)00028-00022.

Khazaradze, G., and J. Klotz (2003), Short- and long-term effects of GPS measured crustal deformation rates along the south central Andes, J. Geophys. Res., 108(B6), 2289, doi:10.1029/2002JB001879.

Labonne, M., and C. Hillaire-Marcel (2000), Geochemical gradients within modern and fossil shells of Concholepas concholepas from northern Chile: An insight into U-Th systematics and diagenetic/authigenic isotopic imprints in mollusk shells, Geochim. Cosmochim. Acta, 64, 1523. Lajoie, K. R. (1986), Coastal Tectonics, Active Tectonics, pp. 95-124, Natl. Acad. Press, Washington D. C.

Lay, T. (2015), The surge of great earthquakes from 2004 to 2014, Earth Planet. Sci. Lett., 409, 133-146, doi:10.1016/j.epsl.2014.10.047.

Le Roux, J. P., C. Tavares Correa, and F. Alayza (2000), Sedimentology of the Rimac-Chillon alluvial fan at Lima, Peru, as related to PlioPleistocene sea level changes, glacial cycles and tectonics, J. South Am. Earth Sci., 13, 499-510, doi:10.1016/S0895-9811(00)00044-4.

Leonard, E. M., and J. F. Wehmiller (1991), Geochronology of marine terraces at Caleta Michilla, northern Chile; implications for late Pleistocene and Holocene uplift, Rev. Geol. Chile, 18, 81-86.

Leonard, E. M., and J. F. Wehmiller (1992), Low uplift rates and terrace reoccupation inferred from mollusk aminostratigraphy, Coquimbo Bay area, Chile, Quatern. Res., 38, 246-259, doi:10.1016/0033-5894(92)90060-V.

Leonard, E. M., D. R. Muhs, K. R. Ludwig, and J. F. Wehmiller (1994), Coral uranium-series ages and mollusc amino-acid ratios from uplifted marine terrace deposits Morro de Copiapo, northcentral Chile, American Quaternary Association Program and Abstracts (AMQUA), 13th Biennal Meeting, 223.

Li, S., M. Moreno, J. Bedford, M. Rosenau, and O. Oncken (2015), Revisiting viscoelastic effects on interseismic deformation and locking degree: A case study of the Peru-north Chile subduction zone, J. Geophys. Res. Solid Earth, 120, 4522-4538, doi:10.1002/2015JB011903.

Lin, Y. N., et al. (2013), Coseismic and postseismic slip associated with the 2010 Maule earthquake, Chile: Characterizing the Arauco Peninsula barrier effect, J. Geophys. Res.Solid Earth, 118, 3142-3159, doi:10.1002/jgrb.50207.

Llenos, A., and J. McGuire (2007), Influence of fore-arc structure on the extent of great subduction zone earthquakes, J. Geophys. Res., 112 B093601, doi:10.1029/2007JB004944.

Lomnitz, C. (1970), Major earthquakes and tsunamis in Chile during the period 1535 to 1955, Int. J. Earth Sci., 59, 938-960.

Lomnitz, C. (2004), Major earthquakes of Chile: A historical survey, 1535-1960, Seismol. Res. Lett., 75, 368-378.

Loveless, J. P., M. E. Pritchard, and N. Kukowski (2010), Testing mechanisms of seismic segmentation with slip distributions from recent earthquakes along the Andean margin, Tectonophysics, 495, 15-33, doi:10.1016/j.tecto.2009.05.008.

Macharé, J., and L. Ortlieb (1992), Plio-Quaternary vertical motions and the subduction of the Nazca Ridge, central coast of Peru, Tectonophysics, 205, 97-108.

Marquardt, C. (2005), Déformations néogènes le long de la côte nord du Chili ( $\left.23^{\circ}-27^{\circ} \mathrm{S}\right)$, avant-arc des Andes centrales PhD thesis, Université de Toulouse III, France, 212 pp.

Marquardt, C., A. Lavenu, L. Ortlieb, E. Godoy, and D. Comte (2004), Coastal neotectonics in southern central Andes: Uplift and deformation of marine terraces in northern Chile (27 S), Tectonophysics, 394, 193-219.

Marshall, J. S., and R. S. Anderson (1995), Quaternary uplift and seismic cycle deformation, Peninsula de Nicoya, Pacific Coast, Costa Rica, Geol. Soc. Am. Bull., 107, 463-473.

Melnick, D. (2016), Rise of the central Andean coast by earthquakes straddling the Moho, Nat. Geosci., 9, 401-407.

Melnick, D., B. Bookhagen, H. Echtler, and M. Strecker (2006), Coastal deformation and great subduction earthquakes, Isla Santa María, Chile (37º), Geol. Soc. Am. Bull., 118, 1463-1480.

Melnick, D., B. Bookhagen, M. R. Strecker, and H. P. Echtler (2009), Segmentation of megathrust rupture zones from fore-arc deformation patterns over hundreds to millions of years, Arauco Peninsula, Chile, J. Geophys. Res., 114, B01407, doi:10.1029/2008JB005788.

Métois, M., A. Socquet, and C. Vigny (2012), Interseismic coupling, segmentation and mechanical behavior of the central Chile subduction zone, J. Geophys. Res., 117, B03406, doi:10.1029/2011JB008736.

Métois, M., A. Socquet, C. Vigny, D. Carrizo, S. Peyrat, A. Delorme, E. Maureira, M.-C. Valderas-Bermejo, and I. Ortega (2013), Revisiting the north Chile seismic gap segmentation using GPS-derived interseismic coupling, Geophys. J. Int., 194, 1283-1294, doi:10.1093/gji/ggt183.

Métois, M., C. Vigny, A. Socquet, A. Delorme, S. Morvan, I. Ortega, and M.-C. Valderas-Bermejo (2014), GPS-derived interseismic coupling on the subduction and seismic hazards in the Atacama region, Chile, Geophys. J. Int., 196, 644-655, doi:10.1093/gji/ggt418.

Métois, M., C. Vigny, and A. Socquet (2016), Interseismic coupling, megathrust earthquakes and seismic swarms along the Chilean subduction zone (38-18S), Pure Appl. Geophys., 173, 1431-1449, doi:10.1007/s00024-016-1280-5. 
Mogi, B. K. (1969), Relationship between the occurrence of great earthquakes and tectonic structures, Bull. Earthqu. Res. Inst., 47, 429-451.

Moreno, M., et al. (2011), Heterogeneous plate locking in the south-central Chile subduction zone: Building up the next great earthquake, Earth Planet. Sci. Lett., 305, 413-424, doi:10.1016/j.epsl.2011.03.025.

Moreno, M., C. Haberland, O. Oncken, A. Rietbrock, S. Angiboust, and O. Heidbach (2014), Locking of the Chile subduction zone controlled by fluid pressure before the 2010 earthquake, Nat. Geosci., 7(4), 292-296.

Moreno, M. S., M. Rosenau, and O. Oncken (2010), 2010 Maule earthquake slip correlates with pre-seismic locking of Andean subduction zone, Nature, 467, 198-202.

Nicol, A., and J. Beavan (2003), Shortening of an overriding plate and its implications for slip on a subduction thrust, central Hikurangi Margin, New Zealand, Tectonics, 22(6), 1070, doi:10.1029/2003TC001521.

Nishenko, S., and W. McCann (1979), Large thrust earthquakes and tsunamis: Implications for the development of forearc basins, J. Geophys. Res., 84(B2), 573-584, doi:10.1029/JB084iB02p00573.

Nocquet, J.-M., et al. (2014), Motion of continental slivers and creeping subduction in the northern Andes, Nat. Geosci., 7(4), 287-291, doi:10.1038/ngeo2099.

Norabuena, E., L. Leffler-Griffin, A. Mao, T. Dixon, S. Stein, I. S. Sacks, L. Ocola, and M. Ellis (1998), Space geodetic observations of Nazca-South America convergence across the central Andes, Science, 279(5349), 358-362, doi:10.1126/science.1279.5349.1358.

Okada, Y. (1992), Internal deformation due to shear and tensile faults in a half-space, Bull. Seismol. Soc. Am., 82, $1018-1040$.

Ortlieb, L., B. Ghaleb, C. Hillaire-Marcel, J. Machare, and P. Pichet (1992), Déséquilibres U/Th, rapports allo/isoleucine et teneurs en 180 des mollusques de dépôts littoraux pléistocènes du sud du Pérou: Une base d'appréciation chronostratigraphique, C. R. Acad. Sci., 314, 101-107.

Ortlieb, L., et al. (1996a), Coastal deformation and sea level changes in northern Chile subduction area (23ㅇ) during the last $330 \mathrm{ky}$, Quat. Sci. Rev., 15, 819-831.

Ortlieb, L., C. Zazo, J. L. Goy, C. Dabrio, and J. Machare (1996b), Pampa del Palo: An anomalous composite marine terrace on the uprising coast of southern Peru, J. South Am. Earth Sci., 9, 367-379.

Osmond, K. (1987), Thorium/uranium disequilibrium age of a suite of mollusc shells from a Peruvian terrace, Abstracts of the XII INQUA Congress, pp. 235, Ottawa.

Pedoja, K., et al. (2011), Relative sea-level fall since the last interglacial stage: Are coasts uplifting worldwide?, Earth Sci. Rev., 108, 1-15, doi:10.1016/j.earscirev.2011.05.002

Perfettini, H., et al. (2010), Seismic and aseismic slip on the central Peru megathrust, Nature, 465, 78-81, doi:10.1038/nature09062.

Pritchard, M., M. Simons, P. Rosen, S. Hensley, and F. H. Webb (2002), Coseismic slip from the 1995 July $30 M_{w}=8,1$ Antofagasta, Chile earthquake as constrained by InSAR and GPS observations, Geophys. J. Int., 150, 362-376, doi:10.1046/j.1365-246X.2002.01661.x.

Pritchard, M. E., and M. Simons (2006), An aseismic slip pulse in northern Chile and along-strike variations in seismogenic behavior, J. Geophys. Res., 111, B08405, doi:10.1029/2006JB004258.

Protti, M., V. González, A. V. Newman, T. H. Dixon, S. Y. Schwartz, J. S. Marshall, L. Feng, J. I. Walter, R. Malservisi, and S. E. Owen (2014), Nicoya earthquake rupture anticipated by geodetic measurement of the locked plate interface, Nat. Geosci., 7, 117-121, doi:10.1038/ngeo2038.

Quezada, J., G. Gonzalez, T. Dunai, A. Jensen, and J. Juez-Larre (2007), Pleistocene littoral uplift of northern Chile: ${ }^{21} \mathrm{Ne}$ age of the upper marine terrace of Caldera-Bahia Inglesa area, Rev. Geol. Chile, 34, 81-96.

Radtke, U. (1987), Palaeo sea levels and discrimination of the last and the penultimate interglacial fossiliferous deposits by absolute dating methods and geomorphological investigations illustrated from marine terraces in Chile, Berliner Geogr. Stud., 25, 313-342.

Radtke, U. (1989), Marine Terrassen und Korallenriffe. Das Probleem der Quartären Meerespiegelschwankungen erlänter an Fallstudien aus Chile, Argentinien und Barbados, Dusseld Geogr Schr., 27, 245.

Regard, V., M. Saillard, J. Martinod, L. Audin, S. Carretier, K. Pedoja, R. Riquelme, P. Paredes, and G. Hérail (2010), Renewed uplift of the central Andes forearc revealed by coastal evolution during the Quaternary, Earth Planet. Sci. Lett., 297, 199-210, doi:10.1016/j.epsl.2010.06.020.

Rehak, K., M. R. Strecker, and H. P. Echtler (2008), Morphotectonic segmentation of an active forearc, $37^{\circ}-41^{\circ} \mathrm{S}, \mathrm{Chile}, \mathrm{Geomorphology,} 94$, 98-116.

Remy, D., H. Perfettini, N. Cotte, J. P. Avouac, M. Chlieh, F. Bondoux, A. Sladen, H. Tavera, and A. Socquet (2016), Postseismic relocking of the subduction megathrust following the 2007 Pisco, Peru, earthquake, J. Geophys. Res. Solid Earth, 121, 3978-3995, doi:10.1002/ 2015JB012417.

Robinson, D. P., S. Das, and A. B. Watts (2006), Earthquake rupture stalled by a subducting fracture zone, Science, 312(5777), $1203-1205$.

Rodriguez, M. P., S. Carretier, R. Charrier, M. Saillard, V. Regard, G. Hérail, S. Hall, D. Farber, and L. Audin (2013), Geochronology of pediments and marine terraces in north-central Chile and their implications for Quaternary uplift in the western Andes, Geomorphology, 180, 33-46.

Rosenau, M., and O. Oncken (2009), Fore-arc deformation controls frequency-size distribution of megathrust earthquakes in subduction zones, J. Geophys. Res., 114, B10311, doi:10.1029/2009JB006359.

Ruegg, J., A. Rudloff, C. Vigny, R. Madariaga, J. B. de Chabalier, J. Campos, E. Kausel, S. Barrientos, and D. Dimitrov (2009), Interseismic strain accumulation measured by GPS in the seismic gap between Constitución and Concepción in Chile, Phys. Earth Planet. In., $175,78-85$.

Ruff, L. J., and B. W. Tichelaar (1996), What controls the seismogenic plate interface in subduction zones?, Geophys. Monogr., 96, 105-111.

Saillard, M. (2008), Dynamique du soulèvement côtier Pléistocène des Andes centrales: Étude de l'évolution géomorphologique et datations (10Be) de séquences de terrasses marines (Sud Pérou-Nord Chili), PhD thesis, Université de Toulouse, France, 308 p.

Saillard, M., S. R. Hall, L. Audin, D. L. Farber, G. Hérail, J. Martinod, V. Regard, R. C. Finkel, and F. Bondoux (2009), Non-steady long-term uplift rates and Pleistocene marine terrace development along the Andean margin of Chile $\left(31^{\circ} \mathrm{S}\right)$ inferred from ${ }^{10}$ Be dating, Earth Planet. Sci. Lett., 277, 50-63.

Saillard, M., S. R. Hall, L. Audin, D. L. Farber, V. Regard, and G. Hérail (2011), Andean coastal uplift and active tectonics in southern Peru: ${ }^{10}$ Be surface exposure dating of differentially uplifted marine terrace sequences (San Juan de Marcona, 15.4 degrees S), Geomorphology, 128, 178-190.

Saillard, M., J. Riotte, V. Regard, A. Violette, G. Hérail, L. Audin, and R. Riquelme (2012), Beach ridges U-Th dating in Tongoy bay and tectonic implications for a peninsula-bay system, Chile, J. South Am. Earth Sci., 40, 77-84.

Savage, J. C. (1983), A dislocation model of strain accumulation and release at a subduction zone, J. Geophys. Res., 88(B6), 4984-4996, doi:10.1029/JB088iB06p04984.

Scholz, C. H. (1998), Earthquakes and friction laws, Nature, 391, 37-42.

Schurr, B., G. Asch, M. Rosenau, R. Wang, O. Oncken, S. Barrientos, P. Salazar, and J. P. Vilotte (2012), The 2007 M7.7 Tocopilla northern Chile earthquake sequence: Implications for along-strike and downdip rupture segmentation and megathrust frictional behavior, J. Geophys. Res., 117, B05305, doi:10.1029/2011JB009030.

Shirzaei, M., R. Burgmann, O. Oncken, T. R. Walter, P. Victor, and O. Ewiak (2012), Response of forearc crustal faults to the megathrust earthquake cycle: InSAR evidence from Mejillones Peninsula, northern Chile, Earth Planet. Sci. Lett., 333, 157-164. 
Siddall, M., J. Chappell, and E.-K. Potter (2006), Eustatic sea-level during past interglacials, in The Climate of Past Interglacials, edited by F. Sirocko et al., pp. 75-92, Elsevier, Amsterdam.

Sladen, A., H. Tavera, M. Simons, J.-P. Avouac, A. O. Konca, H. Perfettini, L. Audin, E. J. Fielding, and F. Ortega (2010), Source model of the 2007 $M_{w}$ 8.0 Pisco, Peru earthquake: Implications for seismogenic behavior of subduction megathrusts, J. Geophys. Res., 115, B02405, doi:10.1029/2009JB006429.

Song, T. A., and M. Simons (2003), Large trench-parallel gravity variations predict seismogenic behavior in subduction zones, Science, 301, 630-633.

Sparkes, R., F. Tilmann, N. Hovius, and J. Hillier (2010), Subducted seafloor relief stops rupture in South American great earthquakes: Implications for rupture behaviour in the 2010 Maule, Chile earthquake, Earth Planet. Sci. Lett., 298, 89-94, doi:10.1016/j.epsl.2010.07.029.

Spence, W., C. Mendoza, E. R. Engdahl, G. L. Choy, and E. Norabuena (1999), Seismic subduction of the Nazca Ridge as shown by the 1996-97 Peru earthquakes, Pure Appl. Geophys., 154, 753-776.

Stevens, V. L., and J.-P. Avouac (2015), Interseismic coupling on the main Himalayan thrust, Geophys. Res. Lett., 42, 5828-5837, doi:10.1002/ 2015 GL064845.

Sunamura, T. (Ed) (1992), Geomorphology of Rocky Coasts, pp. 302, John Wiley, New York.

Thatcher, W. (1990), Order and diversity in the modes of circum-Pacific earthquake recurrence, J. Geophys. Res., 95, 2609-2623, doi:10.1029/ JB095iB03p02609.

Trenhaile, A. S. (1987), The Geomorphology of Rock Coasts, pp. 384, Clarendon Press, Oxford.

Trenhaile, A. S. (2000), Modeling the development of wave-cut shore platforms, Mar. Geol., 166, 163.

van Dinther, Y., T. V. Gerya, L. A. Dalguer, P. M. Mai, G. Morra, and D. Giardini (2013), The seismic cycle at subduction thrusts: Insights from seismo-thermomechanical models, J. Geophys. Res. Solid Earth, 118, 6183-6202.

Victor, P., M. Sobiesiak, J. Glodny, S. N. Nielsen, and O. Oncken (2011), Long-term persistence of subduction earthquake segment boundaries: Evidence from Mejillones Peninsula, northern Chile, J. Geophys. Res., 116, B02402, doi:10.1029/2010JB007771.

Vigny, C., A. Rudloff, J.-C. Ruegg, R. Madariaga, J. Campos, and M. Alvarez (2009), Upper plate deformation measured by GPS in the Coquimbo Gap, Chile, Phys. Earth Planet. Inter., 175(1-2), 86-95.

Von Huene, R., and D. Klaeschen (1999), Opposing gradients of permanent strain in the aseismic zone and elastic strain across the seismogenic zone of the Kodiak shelf and slope, Alaska, Tectonics, 18(2), 248-262, doi:10.1029/1998TC900022.

Wallace, L. M., J. Beavan, S. Bannister, and C. Williams (2012), Simultaneous long-term and short-term slow slip events at the Hikurangi subduction margin, New Zealand: Implications for processes that control slow slip event occurrence, duration, and migration, J. Geophys. Res., 117, B11402, doi:10.1029/2012JB009489.

Wang, K., and S. B. Bilek (2014), Invited review paper: Fault creep caused by subduction of rough seafloor relief, Tectonophysics, 610, 1-24, doi:10.1016/j.tecto.2013.11.024.

Watanabe, H. (1983), Revised catalog of tsunamis around Japan Islands, Zishin, Ser., 2, 83-107.

Wells, R. E., R. J. Blakely, Y. Sugiyama, D. W. Scholl, and P. A. Dinterman (2003), Basin-centered asperities in great subduction zone earthquakes: A link between slip, subsidence, and subduction erosion?, J. Geophys. Res., 108(B10), 2507, doi:10.1029/2002JB002072. 